\title{
Pemanfaatan Modal Sosial dalam Upaya Meningkatkan Kemandirian Mantan Tenaga Kerja Indonesia di Kabupaten Lampung Timur
}

\author{
Diana Ambarwati \\ Institut Agama Islam Negeri (IAIN) Metro Lampung, Indonesia \\ Diana.ambarwati29@gmail.com
}

\begin{abstract}
This article will focus on how social capital namely trust, norms, network, reciprocity can be used to increase the independence of former Indonesian Workers in the Rintisan Market of TKI in East Lampung, by conducting field research and using a sociological approach.

Being economically independent is a dream of every ex-migrant worker in East Lampung. The social capital that is owned is enough to deliver to the independence of former migrant workers economically. The social capital owned by former migrant workers in East Lampung includes (1) trust. High trust (hight trust) will produce the willingness and courage to cooperate. (2) Norm (applicable social order / institution). The agreed norms make everyone act as the basis of the agreement and common goals of the community of former migrant workers who are developing economic independence. (3) Network (network between members), a strong network makes ex-migrant workers quickly get information both related to suppliers, market opportunities, and new business opportunities, as well as opportunities to get training education in collaboration with outside parties. (4) Reciprocity is what then makes the members of Labuhan Ratu market as fellow ex-migrant workers who share the same interests to help each other, strengthen each other and motivate each other to achieve independence. To see how much social capital has an influence on increasing the independence
\end{abstract}


of former migrant workers. Broadly speaking, social capital has a positive influence on increasing the independence of migrant workers in Labuhan Ratu East Lampung.

Keywords: social capital, trust, norms, network, resiprosity, independence, former migrant workers.

\begin{abstract}
Abstrak
Artikel ini akan memfokuskan pada bagaimana modal sosial yakni trust, norms, network, reciprocity dapat dimanfaatkan untuke meningkatkan kemandirian mantan Tenaga Kerja Indonesia di Pasar Rintisan TKI Lampung Timur, dengan melakukan field research dan menggunakan pendekatan sosiologis.

Menjadi mandiri secara ekonomi adalah mimpi setiap mantan TKI di Lampung Timur. Modal sosial yang dimiliki cukup untuk. mnghantarkan pada kemandirian mantan TKI secara ekonomi. Modal sosial yang telah dimiliki mantan TKI di Lampung Timur meliputi (1) kepercayaan (trust). Kepercayaan yang tinggi (bight trust) akan menghasilkean kemauan dan keberanian untuk bekerjasama. (2) Norm (tatanan/pranata sosial yang berlaku). Norma yang disepakati bersama menjadikan setiap orang bertindak atass dasar kesepakatan dan tujuan bersama dari komunitas mantan TKI yang sedang membangun kemandirian ekonomi. (3) Network (jaringan antar anggota), jejaring yang kuat menjadikan para mantan TKI cepat mendapatkan informasi baik berkaitan dengan pemasok, peluang pasar, dan peluang usaha baru, serta peluang mendapatkan pendidikan pelatihan bekerjasama dengan pihak luar. (4) Reciprocity (bubungan timbal-balik) inilah yang kemudian menjadikan anggota pasar Labuban Ratu sebagai sesama mantan TKI yang senasib sepenanggungan untuk saling membantu, saling menguatkan dan saling memotivasi untuk mencapai kemandirian. Untuk melihat seberapa besar modal sosial memberikan pengaruh terhadap peningkatan kemandirian mantan TKI. Secara garis besar modal sosial memberikan pengaruh positif bagi peningkatan kemandirian TKI di Labuban Ratu Lampung Timur.
\end{abstract}

Kata Kunci: modal social, trust, norm, network, resiprosity, kemandirian, mantan TKI 


\section{A. Pendahuluan}

Berdasarkan data Badan Pusat statistik didapatkan bahwa jumlah pengangguran di Indonesia pada tahun 2012 mencapai 7.244.956 jiwa. Keberadaan jumlah penduduk yang tinggi menyebabkan Indonesia menghadapi berbagai permasalahan tentang kependudukan. Masalah yang dihadapi meliputi kesehatan, kesejahteraan, kondisi perekonomian dan penyerapan tenaga kerja. Penyerapan tenaga kerja yang rendah menyebabkan tingkat pengangguran menjadi tinggi. Sampai dengan saat sekarang ini, masalah ketenagakerjaan ini masih banyak yang belum bisa diatasi oleh pemerintah. ${ }^{1}$ Demikian pula dengan data yang dirilis oleh Bank Indonesia (BI) dan BNPTKI menyatakan bahwa pada tahun 2016 terdapat 3.459.000 orang $^{2}$ warga Negara Indonesia yang menjadi tenaga kerja Indonesia (TKI) di luar negeri. Mereka tersebar di negara-negara ASEAN, ASIA selain ASEAN, dan Timur Tengah. Dan sebanyak 3.314 orang diantaranya adalah warga Lampung Timur $^{3}$ dan penyumbang terbesar tenaga kerja Indonesia (TKI) adalah kecamatan Labuhan Ratu, Way Jepara dan desa yang terbanyak kedua adalah Desa Buana Sakti Kecamatan Batanghari. ${ }^{4}$

Terdapat beberapa faktor penyebab sekian banyak warga Negara Indonesia memilih untuk meninggalkan tanah air dan mengadu nasib di negeri seberang menjadi tenaga kerja Indonesia (TKI). Beberapa faktor yang mengemuka diantaranya adalah minimnya permintaan tenaga kerja di Indonesia, ${ }^{5}$ menjadi salah

1 Jannes Eudes Wawa, Ironi Pablawan Devisa, Jakarta; PT Kompas Media Nusantara, 2005), h. 39

2 Bank Indonesia and BNP2TKI

3 Barly Sputra Utama, Kasi Penempatan Tenaga kerja Lampung Timur, dalam https://kupastuntas.co, tanggal 11 Oktober 2017

4 Yunita Rohani, Ketua SBMI Lampung dan Pendiri kampung Buruh Migran Lampung, wawancara, tanggal 18 April 2015

5 Terdapat dua faktor yang menjadi penghambat dalam mendapatkan akses pekerjaan. Pertama, faktor yang berasal dalam diri angkatan kerja atau faktor internal dari para pemburu akses kerja, yakni rendahnya kualitas sumber daya manusia karena tingkat pendidikan (keterampilan) atau kesehatan rendah atau ada hambatan budaya (budaya kemiskinan). Walaupun akses dan kesempatan ada ketika kualitas SDM nya tidak memenuhi syarat dengan sendirinya akses itu terbatasi oleh orang tersebut. Selanjutnya kedua faktor ekternal yakni faktor yang berasal dari luar diri atau. Faktor ekternal ini adalah 
satu penyebab banyak orang untuk memutuskan bekerja menjadi tenaga kerja. Selain factor di atas yang menjadi factor pemicu adalah dorongan dari orangtua, ${ }^{6}$ mencari penghasilan yang lebih besar, mencari pengalaman kerja, mencari pasangan hidup, menjadi warga negara asing, ${ }^{7}$ dan menjadi seorang juru dakwah. Namun, demikian diantara itu semua hal yang paling dominan adalah faktor ekonomi. ${ }^{8}$ Banyak orang tergiur dengan iming-iming gaji besar dengan bekerja di luar negeri. Jika dibandingkan Propinsi Jakarta ditetapkan UMR adalah sebesar Rp. 3.355.750 per bulan, ${ }^{9}$ ini akan jauh berbeda jika bekerja di Korea Selatan yang mematok gaji karyawannya sebesar 1.375 Won, atau setara dengan Rp 16 juta per bulan. ${ }^{10}$

Namun, pada akhirnya setiap pekerja di luar negeri, tetap juga memiliki mimpi untuk pulang ke tanah air, kembali ke kampung halaman untuk berkumpul dan hidup bersama keluarganya dan mandiri secara ekonomi. Untuk mencapai mimpi itu maka diperlukan persiapan yang benar-benar matang bagi pekerja migran Indonesia dan keluarganya. Dan tidak terpeleset gaya hidup mewah dan menghamburkan hasil kerja untuk berfoya-foya. ${ }^{11}$ Fenomena tersebut menjadi salah satu "benang kusut" dan sangat dilematis. Kasuistik demikian, tidak hanya menimpa satu dua orang pekerja,

berkaitan dengan kebijakan pemerintan ataupun stakeholder jugs dapat membatasi atau memperkecil akses seseorang untuk memanfaatkan kesempatan dan peluang yang tersedia. Hal tersebut di atas secara makro dapat dilihat bahwa minimnya akses yang disediakan oleh pemerintah untuk mendapatkan peluang kerja di tanah air. Peluang kerja haruslah disediakan dan diciptakan mengingat setiap tahun angkatan kerja di Indonesia meningkat tajam. Hal ini seiring dengan pertumbuhan penduduk. Tak salah jika pemerintah telah menetapkan tahun 2025 Indonesia memiliki bonus demografi. Tingginya angkatan kerja menjadi tantangan tersendiri bagi pemerintah dan seluruh rakyat Indonesia.

6 Sevita Dwi Yani, Banyak Remaja Menjadi Buruh Migran Karena Dorongan Orang Tua, https://buruhmigran.or.id, diakses 5 Agustus 2018.

7 Alasan Penyebab Seseorang Menjadi TKI (Tenaga Kerja Indonesia) ke Luar Negeri, dalam http://www.organisasi.org, diakses 5 Agustus 2018

8 Imam Nahrowi, wawancara via telp, 23 Juli 2018. Dalam pengakuannya ia menjadi juru dakwah di Korea selama 5 tahun lebih dengan status tenaga kontrak. Tugas sehari-harinya adalah mengumandangkan azdhan setiap waktu sholat, menyiapkan tempat sholat dan ceramah dari masjid ke masjid di Korea.

Okt 2016

9 UMR DKI Jakarta tahun 2017 dalam http://bisnis.liputan6.com, tanggal 28

10 https://bisnis.tempo.com, tanggal 27 April 2017

11 Imam Nahrowi, Mengembangkan Ekonomi TKI, Peluang dan tantangan (sebuab pemikiran), artikel tidak diterbitkan. 
namun hampir menimpa banyak pekerja migran yang ada di Kabupaten Lampung Timur.

Fenomena ini menunjukkan ketidaksiapan yang dilatarbelakangi ketidaktahuan dalam mengelola uang hasil jerih payah bekerja di luar negeri, membuat para mantan TKI terjebak pada perangkap untuk memenuhi kebutuhan sesaat, lalai untuk menyisakan sebagian uangnya sebagai bentuk modal usaha. Rentetan ketidakberdayaan TKI itu banyak berujung pada fenomena kembalinya mantan TKI bekerja ke luar negeri. Artinya buruknya cara pengelolaan hasil kerja di luar negeri yang secara umum menimpa para mantan TKI. Kondisi inilah yang kemudian memicu para TKI yang masih aktif ataupun mantan tenaga kerja Indonesia (TKI) untuk merintis dunia usaha guna memanfaatkan hasil kerja yang didapatkan. Secara bersama-sama, mereka memulai dunia usahanya. Dengan bermodalkan pengalaman pahit yang mendera dan jejaring (networking) dengan tenaga kerja Indonesia (TKI) yang masih aktif, para buruh migran tersebut membangun pasar desa yang sudah mati dan menjadikan nama pasar tersebut dengan nama pasar rintisan TKI. Gayungpun bersambut, karena adanya kepercayaan (trust) terhadap penggerak pasar rintisan tenaga kerja Indonesia (TKI), maka para tenaga kerja Indonesia (TKI) pun turut menginvestasikan untuk meramaikan pasar, baik dengan cara tunai maupun dibangunkan dulu kios baru membayar kemudian. ${ }^{12}$

Kini pasar ini menjadi pasar percontohan secara nasional tentang kemandirian mantan tenaga kerja Indonesia (TKI) di Indonesia. Bentuk-bentuk kemandirian seperti inilah yang kemudian seharusnya dijadikan prioritas bagi para mantan tenaga kerja Indonesia (TKI) dan juga stakeholder di negeri ini. Pada satu sisi, kemandirian yang diciptakan ini akan memberikan peluang bagi masyarakat untuk membangun diri dan berdikari di negeri

12 Imam Nahrowi, wawancara pribadi via whatapps, tanggal 23 Juli 2018. Lihat Yulvianus Harjono, Memelopori Pasar Rintisan Mantan TKI, pada laman, http://internasional. kompas.com, diakses pada 4 Oktober 2017 
sendiri, dan tidak tertarik lagi menjadi TKI. Pada aspek lain, bagi pemerintah, hal ini merupakan salah satu program yang harus didorong (push) dalam rangka untuk menciptakan peluang kerja baru bagi masyarakat luas yang ingin mengais rezekinya dengan cara berkerja. Keberhasilan para mantan tenaga kerja Indonesia (TKI) di Kecamatan Labuhanratu Kabupaten Lampung Timur, dalam menghidupkan kembali pasar, dan menjadi motor penggerak, secara tidak langsung memberikan pengetahuan baru bahwa sesungguhnya terdapat hubungan antara bentuk-bentuk sosial dan interaksi ekonomi telah menghadirkan betapa pentingnya faktor sosial dalam perkembangan pasar. $^{13}$

Pasar harus dimaknai sebagai sebuah rangkaian institusi sosial dimana sejumlah komoditas dari berbagai tipe dipertukarkan secara regular, dan terkadang diprasaranai oleh institusi-institusi tersebut. ${ }^{14}$ Artinya ada jaringan (networking) yang coba dibangun bersama demi tujuan komunitas, ada kepercayaan (trust), dan juga ada hubungan timbal balik (resiptory) yang ingin dicapai bersama dalam komunitas mereka yakni mantan tenaga kerja Indonesia (TKI). Inilah persoalan sebenarnya yang menjadi titik pangkal penelitian ini. Telah banyak upaya yang dilakukan oleh banyak pihak; baik dari pemerintah, swasta maupun swadaya dari para mantan TKI, untuk menekan angka kesulitan selama dan pasca pulang ke tanah air. Eratnya jiwa sama rasa, senasib sepenanggungan, kekeluargaan dan kekerabatan yang dimiliki oleh para mantan TKI harusnya mejadi kekuatan bersama untuk memproteksi diri dari kesulitan, ketidakmandirian secara ekonomi pasca pulang ke tanah air. Dan menjadi menarik untuk diteliti persoalan ini, sehingga rumusan masalah yang diajukan dalam penelitian ini adalah bagaimanakah modal sosial yakni trust (saling percaya), norms (norma), network (jejaring), reciprocity (hubungan timbal-balik), dapat dimanfaatkan guna meningkatkan kemandirian mantan tenaga kerja Indonesia di Pasar Rintisan TKI Labuhan Ratu

13 Pheni Chalid, Sosiologi Ekonomi, (Jakarta: CSES Press, 2009, h. 43

14 Pheni Chalid, Sosiologi Ekonomi...., h. 44 
Lampung Timur?. Dengan melakukan field research yang berlokasi di sebuah Kabupaten Lampung Timur dan menggunakan pendekatan sosiologis maka pertanyaan di atas digali dan dielaborasi.

\section{B. Pembahasan}

\section{Urgensi Modal Sosial dalam Pengembangan Ekonomi}

Membicarakan literatur tentang modal sosial cukup banyak, bahkan dapat dikatakan sangat melimpah. Namun dari semua pandangan tentang modal sosial, sumber relevan yang sering digunakan oleh para penulis dan peneliti modal sosial adalah Coleman, Putnam, Fukuyama dan Bourdieu. ${ }^{15}$ Modal (capital) merupakan kata kunci yang memiliki daya dukung terhadap gerak dan majunya kegiatan ekonomi. Modal sosial juga menjadi bagian istilah dalam sosiologi yang sukses digunakan dalam berbagai pendekatan keilmuan diantaranya ilmu ekonomi, politik dan antropologi. ${ }^{16} \mathrm{Pada}$ bagian ini, modal sosial bukan hanya menjelaskan hubungan pribadi yang membantu dalam mencapai tujuan bersama, memainkan poin terhadap penjelasan tentang bagaimana hubungan sosial manusia menjadi penting sebagai sebuah analisis interaksi bagi perilaku manusia.

Sebenarnya pembahasan tentang modal sosial (social capital) bukanlah konsep yang baru muncul. Konsep ini sudah dibicarakan oleh para ahli ekonomi, kirakira pada abad 19 yang lalu. ${ }^{17}$ Namun demikian, istilah modal sosial itu baru muncul untuk pertama kalinya pada tahun 1916 ketika Lyda Hudson Hanifan menulis tentang The Rural School Community Center. ${ }^{18}$ Perbincangan tentang modal sosial

15 St Agung Dwi Pramono, Pengaruh Modal Sosial Terbadap Kemiskinan Rumah Tangga, Jurnal: Jejak, Vol 7, h.11-229

16 Glenn A Bowen, Sosial Capital, Social Fund And Poor Community, An Explory Analysis, Journal Compilation, Social Policy And Administrations, (Oxford: BlackwellPublishing Ltd, 2009), h.1

17 Castiglione, et.al.. Social Capital's Fortune : An Introducti. In Dario Castiglione, et.al (ed), The Handbook of Social Capital, (New York : Oxford University Press Castiglione, et.al.2008), h.2, lihat juga Pheni Chalid, Sosiologi Ekonomi, (Jakarta: CSES Press, 2009), h. 101

18 M Moelyono, Menggerakean Ekonomi Kreatif Antara Tuntutan dan Kebutuhan, (Jakarta : PT. Raja Grafindo Persada, 2010), h.22 
ini semakin mengemuka, dikarenakan para ahli ekonomi menyadari bahwa untuk menggerakkan aktivitas ekonomi, tidak semata-mata bertumpu atau bertolak pada modal manusia, modal fisik, maupun modal finansial, akan tetapi ada jenis modal lain yang ternyata efektif dalam melumasi kegiatan ekonomi, bahkan dapat memperoleh hasil yang lebih baik ketimbang hanya mengandalkan modal manusia, fisik, dan finansial, yaitu modal sosial. ${ }^{19}$

Hal ini sejalan dengan argumen Lin yang menekankan hubungan modal sosial untuk jaringan sosial operasional sebagai sumber daya yang tertanam dalam jaringan dan diakses kemudian digunakan para pelaku untuk beertindak. Argumen Lin ini tampaknya sejalan dengan Potes dan Sensenbrener yang memakai modal sosial sebagai sebuah harapan dan tindakaan kolektif yang mempengaruhi tujuan ekonomi. ${ }^{20}$ Berbicara modal sosial muncul beberapa perdebataan mengenai tema yang diusung yakni modal ekonomi dan modal sosial. Berbicara modal ekonomi maka setidaknya terdapat 3 jenis modal, yaitu: likuiditas (modal), lahan (land) dan tenaga (labor). Pendekatan sosiologis telah memperluas dimensi dalam spectrum bahwa terdapat faktor-faktor di luar produksi dan non ekonomi yang dapat didayagunakan untuk mendatangkan keuntungan ekonomis, bersumber dari sosialitas seseorang. Modal tersebut sebagai modal sosial. $^{21}$

Modal sosial dapat membuka peluang bisnis dengan adanya pertukaran informasi yang membuat alokasi produk menjadi dinamis, meminimalkan resiko dengan mengambil keuntungan dari jaringan di luar ekonomi. Resiko terbesar dalam ekonomi adalah berasal dari luar dan modal sosial dapat dioperasionalisasikan untuk menekan faktor resiko tersebut. ${ }^{22}$ Memiliki modal sosial menyebabkan individu atau komunitas memiliki keunggulan komparatif yang yang akan

19 St Agung Dwi Pramono, Pengarub Modal Sosial..., h.117-229

20 Lindon J Robinson, A. Allan Schmid, Marcelo E. Siles, Is Social Capital Really Capital, Review Of School Ecomony, 2000, dalam http://papers.ssrn.com

21 Pheni Chalid, Sosiologi Ekonomi..., h. 99

22 Takashi Omori, Economic Effects Of Sosial Capital, Economic and Sosial Research Institut, Cabinet Office, Government Of Japan, March 2003, h. 4-5 
berdampak positif bagi terbukanya peluang atau kesempatan usaha dan budaya baru. ${ }^{23}$ Menurut World Bank, social capital adalah “...a society include the institution, the relationships, the attitude and value that govern interactions among people and contribute to economic and social development". ${ }^{24}$ Putnam melakukan riset tentang social connection (keterhubungan sosial) di masyarakat Amerika dan kemudian mendefinisikan modal sosial sebagai berikut:

"The idea at the core of the theory of social capital is extremely simple: Social networks matter. Networks have value. We describe social networks and the associated norms of reciprocity as social capital, because like physical and buman capital (tools and training), social networks create value, both individual and collective, and because we can-invest in networking. Social networks are, however, not merely investment goods, for they often provide direct consumption value". ${ }^{25}$

23 Pheni Chalid, Sosiologi Ekonomi..., h.101

24 The World Bank, The Initiative On Defining, Monitoring And Measuring Social Capital: Text Of Proposal Approved For Funding, Social Capital Initiative working paper No. 2 the world bank development family, environmentally and socially sustainable development network, June 1998 (dalam http://.worldbank.org yang dikutip dalam syahyuti, Social Capital, Pusat Kebijakan Sosial ekonomi dan Pertanian IPB.

25 Robert D. Putnam, seorang ahli Ilmu Politik asal Amerika beberapa kali merubah definisinya tentang modal sosial yakni pertama, features of social organisation, such as trust, norms, and networks, than can improve the efficiency of society by facilitating coordinated action. (Sesuatu karakteristik yang ada di dalam organisasi sosial, semisal kepercayaan, norma, dan jejaring yang bisa memperbaiki efisiensi masyarakat melalui memfasilitasi aksi-aksi yang terkoordinasikan). Defines kedua dirumuskan pada tahun 1996, Putnam sedikit merevisi definisi yang telah digulirkan sebelumnya, yaitu: by social capital' I mean features of social life-networks, norms and trust-that enable participants to act together more effectively to pursue shared objectives. (dengan - modal sosial, aku memaksud-kannya adalah fitur-fitur kehidupan sosial, semisal jejaring, norma, dan kepercayaan, yang kesemuanya bisa digunakan oleh partisipan untuk berbuat bersama secara lebih efektif untuk mencapai tujuan bersama). Dan pada tahun 2002, merevisi definisinya dengan The idea at the core of the theory of social capital is extremely simple: Social networks matter. Networks have value, ... We describe social networks and the associated norms of reciprocity as social capital, because like physical and human capital (tools and training), social networks create value, both individual and collective, and because we can-invest merely investment goods, for they often provide direct consumption value. (Ide utama dari teori modal sosial adalah sangat sederhana: tentang jejaring sosial. Jejaring memiliki nilai ... dst. Kami jelaskan bahwa jejaring sosial dan normanorma yang terkait resiprositas (saling memberi, saling merespon) sebagai modal sosial, karena seperti modal fisik dan modal manusia (peralatan dan trainning), jejaring sosial menciptakan nilai bagi dua pihak, individu dan kelompok, dan karena kita bisa melakukan investasi dalam jejaring. Jejaring sosial adalah tidak hanya investasi barang semata, bagi mereka seringkali memberikan nilai konsumsi langsung. Lihat Robert Putnam, Democracies in Flux: The Evolution of Social Capital in Contemporary Society, (New York: Oxford University Press, 2002), h. 50 
Namun modal sosial tidaklah sesederhana hanya sebagai jumlah dari seluruh institusi yang ada. Modal sosial berfungsi semacam perekat yang mengikat semua orang dalam masyarakat. Dalam modal sosial dibutuhkan adanya "nilai saling berbagi" (shares value) serta pengorganisasian peran-pran (rules) yang diekpresikan dalam hubungan personal (personal relationships), kepercayaan (trust) dan common sense tentang tanggungjawab bersama; sehingga masyarakat menjadi lebih dari sekedar kumpulan individu belaka.

Modal sosial menurut Fukuyama memiliki dimensi yang luas menyangkut segala sesuatu yang membuat masyarakat bersekutu untuk mencapai tujuan bersama atas dasar kebersamaan, dan di dalamnya diikat oleh nilainilai dan norma-norma yang tumbuh dan dipatuhi. ${ }^{26}$ Sebagai mahluk sosial, manusia tidak bisa hidup sendiri. Manusia membutuhkan manusia lain untuk bekerjasama. Di tengah relasi tersebut akan muncul peran modal sosial. Modal sosial dalam studi sosiologi klasik bersumber dari (a) nilai introjeksi, (b) transaksi resiprositas, (c) Ikatan solidaritas dan (d) kepercayaan (trust). ${ }^{27}$ Lebih lanjut Fukuyama mengatakan jika rasa saling percaya (trust) merupakan elemen inti dari modal sosial (social capital). Artinya, bila pembangunan dalam segala aspek ingin berhasil, maka pembangunan tersebut harus didasari oleh adanya trust, dan selanjutnya pembangunan tersebut harus mampu mengkreasi sedemikian rupa sehingga trust terus terakumulasi. Bahwa kepercayaan dalam bisnis merupakan elemen mendasar dalam suatu kesuksesan bisnis. Selain itu bisnis membutuhkan interaksi sosial dan jaringan. ${ }^{28}$

Di Indonesia, modal sosial menjadi bahan kajian yang menarik, mengingat besarnya potensi modal sosial di Indonesia. Selanjutnya, di luar sana, hadir pemahaman yang terus berkembang, ternyata modal sosial merupakan salah satu faktor penentu dalam pembangunan ekonomi. Menyikapi hal ini, Field mengemukakan

26 Dodi Faedlulloh, Modal Sosial Dalam Gerakan Koperasi, Jurnal: IJPA-The Indonesian Journal Of Public Administration, Volume 2, Nomor 1, Nopember 2015

27 Pheni Chalid, Sosiologi Ekonomi..., h. 101-102

28 Pheni Chalid, Peranan Modal Sosial Dalam Kegiatan Ekonomi, Signifikan Vol. 1 No. 1 April 2012 
bahwa gagasan sentral dari modal sosial adalah jaringan sosial merupakan aset yang bernilai. Jaringan memberikan dasar bagi kohesi sosial karena mendorong orang bekerja sama satu sama lain dan tidak sekadar dengan orang yang mereka kenal secara langsung untuk memperoleh manfaat timbal balik. ${ }^{29}$

Seperti halnya modal lainnya, modal sosial juga produktif, membuat suatu tujuan akhir menjadi mungkin untuk dicapai. Tujuan tersebut tidak akan tercapai bila modal ini tidak ada. Lebih rinci menurut Putnam manfaat modal sosial antara lain: pertama, memungkinkan masyarakat memecahkan masalah-masalah bersama dengan mudah. Kedua, menumbuhkan rasa saling percaya dalam hubungan sosial untuk mewujudkan kepentingan bersama. Ketiga, memungkinkan terciptanya jaringan kerja sama sehingga mudah mendapatkan informasi. ${ }^{30}$ Dengan demikian sesungguhya modal sosial dapat dimanfaatkan untuk membangun ekonomi sebuah komunitas. Dan komunitas mantan tenaga kerja Indonesia (TKI) di Labuhan Ratu telah membuktikannya, betapa perekonomian dan taraf hidup keluarga dapat meningkat dengan adanya pasar rintisan TKI ini.

\section{Modal Sosial: Bridging Menuju Kemandirian Mantan TKI di Lampung Timur}

Baru-baru ini Balai Pelayanan Penempatan dan Perlindungan Tenaga Kerja Indonesia (BP3TKI) Lampung merilis data tentang TKI di Lampung. Kabupaten Lampung Timur memiliki 5.469 pekerja di luar negeri di berbagai Negara, dengan rincian 3.804 pekerja pada sektor informal dari 10 laki-laki dan 3.794 perempuan. Kemudian 1.665 pekerja sektor formal dari 1.441 laki-laki dan 224 perempuan. Kepala BP3TKI Lampung A. Salabi melalui Pengantar Kerja Pertama Azsma Zahratun Nabila mengatakan Lampung Timur memang menjadi kantung persebaran tertinggi tenaga kerja

29 J Field, Modal Sosial, (Bantul: Kreasi Wacana, 2010), h.18

30 R.D Putnam, Bowling Alone: The Colapse and Revival of American Community, (New York: Touchstone, 2000), h. 167 
Indonesia (TKI) selama beberapa tahun terakhir. ${ }^{31}$ Sedangkan kecamatan Labuhan Ratu menurut data Serikat Buruh Migran Indonesia (SBMI) merupakan pemasok Tenaga kerja Indonesia asal Lampung terbanyak di Lampung. ${ }^{32}$

Namun demikian, besarnya angka tenaga kerja Indonesia di kecamatan Labuhan Ratu menjadi peluang bagi mantan TKI untuk secara kolektif membangun kemandirian pasca kembali dari luar negeri. Demikianlah yang dilakukan mantan TKI yang berada di kecamatan Labuhan Ratu dan sekitarnya, dengan mentransformasi sebuah pasar desa ${ }^{33}$ yang masih tradisional yang telah beberapa tahun

31 Lihat Lampung Timur Penyumbang Pekerja Migran Terbanyak, dalam http:// www.lampost.com, 03 May 2018

32 Yunita Rohani, Ketua SBMI Lampung dan Pendiri kampung Buruh Migran Lampung, wawancara, tanggal 18 April 2018

33 Pasar desa yang dimaksud adalah pasar yang dikelola oleh Pemerintah Desa. Pasar desa (tradisional) merupakan sebuah aset ekonomi dan budaya di tingkat desa, tetapi seiring perkembangan pasar modern yang begitu pesat lambat laun mengancam keberadaan pasar tradisional. Namun di Desa ini pasar desa keberadaannya belum dikelola secara profesional dan menimbulkan permasalahan sosial di tengah masyarakat seperti kesemrawutan dan kekumuhan. Perlu upaya penataan dan pembinaan dalam pengelolaan pasar-pasar desa tersebut, demi terwujudnya desa yang maju, kuat, mandiri dan demokratis serta memberikan kontribusi terhadap pembangunan daerah. Pembangunan pasar desa dapat dilakukan secara mandiri oleh BUMDesa atau melalui kerja sama dengan pihak lain atau swasta. Selain bangunan utama pasar yang berisi lapak/kios tempat usaha, bangunan pasar juga harus dilengkapi dengan sarana pendukung seperti: kantor pengelola, area parkir, tempat pembuangan dan pengelolaan sampah sementara, air bersih, sanitasi atau drainase, tempat ibadah, toilet umum, pos keamanan, tempat pengolahan air limbah, hydran dan fasilitas pemadam kebakaran, penteraan, sarana komunikasi, serta area bongkar-muat dagangan. Pengelola Operasional (PO) pasar desa sebaiknya harus terpisah dari Pemerintahan Desa. PO pasar desa dipilih melalui musyawarah desa dan ditetapkan dengan Keputusan Kepala Desa. PO pasar desa terdiri dari Kepala Pasar yang dalam menjalankan tugasnya dibantu oleh beberapa karyawan yang bertugas menangani bagian umum, keamanan dan parkir, keuangan dan administrasi, serta pemeliharaan. Penerimaan pendapatan pasar desa sendiri selain sewa tempat usaha serta penjualan dan perpanjangan hak pemakaian tempat usaha, dapat berupa berbagai macam, contohnya adalah jasa keamanan dan kebersihan, jasa parkir, jasa mandi, cuci dan kakus (MCK), jasa listrik dan air bersih yang besaran tarifnya diatur dalam AD/ART BUMDesa dan ditetapkan melalui Peraturan Kepala Desa. Apa yang dipaparkan di atas adalah sebuah impian pengelolaan pasar desa. Namun tidak demikian yang terjadi di Desa Labuhan Ratu kecamatan Labuhan Ratu Kabupaten Lampung Timur. Keberadaan pasar desa yang telah ada sejak tahun 1960-an dan memiliki luas 1 Hektar inilah yang menjadi wilayah perebutan antara aparat desa sebagai pemilik lahan dan mempunyai hak penuh atas pasar desa tersebut dengan pedagang pasar yang notabene mantan TKI dan keluarga TKI. Maka berikut akan dipaparkan kronologi transformasi pasar desa menjadi pasar rintisan TKI dan akhirnya kembali menjadi pasar desa milik desa Labuhan Ratu Kecamatan labuhan Ratu Kabupaten Lampung Timur. Sebuah pasar kecil yang terapit dua pasar besar yakni pasar Tridatu dan pasar Way Jepara. Keduanya adalah pasar milik kecamatan yang usianya cukup 
ditinggalkan konsumen dan pedagangnya menjadi sebuah pasar produktif yang harapannya dapat menjadi penopang perekonomian masyarakat desa labuhan ratu dan sekitarnya. Pasar rintisan TKI itulah nama yang tersemat pada pasar desa tersebut. Suasana kumuh, tak terawat, sepi dan sunyi inilah kesan ketika melihat pasar beberapa tahun lalu sebelum bertransformasi menjadi pasar rintisan TKI.

Usaha membangun pasar ini, oleh penulis dimaknai sebagai upaya membangun kemandirian secara ekonomi sehingga tidak terjebak kepada ketergantungan pada orang atau pihak lain. Kemandirian adalah kata sifat yang memiliki kata dasar mandiri yang mendapatkan awalan "ke" dan akhiran "an" yang kemudian membentuk suatu kata keadaan yang jika ditilik dalam Kamus Besar bahasa Indonesia bermakna hal atau keadaan dapat berdiri sendiri tanpa bergantung pada orang lain. ${ }^{34}$ Kata lain kemandirian adalah independence yakni suatu kondisi dimana seseorang tidak tergantung pada orang lain dalam menentukan keputusan dan adanya sikap percaya diri. ${ }^{35}$ Selanjutnya Monks, dkk mengatakan bahwa orang yang mandiri akan memperlihatkan perilaku yang eksploratif, mampu mengambil keputusan, percaya diri dan kreatif. ${ }^{36}$

Lerner berpendapat konsep kemandirian (autonomy) mencakup kebebasan untuk bertindak, tidak tergantung kepada orang lain, tidak terpengaruh lingkugan dan bebas mengatur kebutuhan sendiri. Demikian juga memiliki kebebasan untuk mengambil inisiatif, mengatasi hambatan, gigih dalam usaha, dan melakukan sendiri segala sesuatu tanpa bantuan orang lain. Karena kemandirian sejati telah tegas digariskan sebagai cita-cita nasional yang harus direalisasi, melepaskan diri dari ketergantungan. ${ }^{37}$

tua dan dengan lokasi yang luas, sehingga mampu menampung banyak masyarakat yang ingin menjadi pedagang di daerah tersebut. Berikut suasana pasar desa Labuhan Ratu yang kemudian keberadaandan eksistensinya menuai polemik dan perebutan yang akan dibahas pada pembahasan tulisan ini.

34 https://kbbi.kemdikbud.go.id/entri/kemandirian

35 J.P. Chaplin, Kamus Lengkap Psikologi, (Jakarta: RajaGrafindo Persada, 2011), h.

36 Monks, dkk, Psikologi Perkembangan: Pengantar Dalam Berbagai Bagian, (Yogyakarta: Gadjah Mada University Press, 1994), h.279

37 Sri-Edi Swasono, Kemandirian Ekonomi: Menghapus Sistem Ekonomi Subordinasi 
Konsep kemandirian menjadi faktor sangat penting dalam pembangunan ekonomi masyarakat. Konsep ini tidak hanya mencakup pengertian kecukupan diri (self-sufficiency) di bidang ekonomi, tetapi juga meliputi faktor manusia secara pribadi, yang di dalamnya mengandung unsur penemuan diri (self-discovery) berdasarkan kepercayaan diri (self-confidence). Kemandirian adalah satu sikap yang mengutamakan kemampuan diri sendiri dalam mengatasi pelbagai masalah demi mencapai satu tujuan, tanpa menutup diri terhadap pelbagai kemungkinan kerjasama yang saling menguntungkan. Artinya sikap mandiri memiliki cirri-ciri pertama, selalu berorientasi pada kualitas dan prestasi. Kedua, mewujudkan aktualisasi dirinya dengan kerja keras dan memfokuskan diri. Ketiga, memberikan sikap dan tindakan terbaik terhadap apa yang sedang dilakukan. Keempat, bersinergi untuk berkontribusi dalam mencapai tujuan. kelima, berorientasi pada tujuan-akhir dengan memperhatikan proses. ${ }^{38}$

Keinginan mantan TKI untuk mandiri sebagaimana uraian sebelumnya inila yang menjadi pemicu gagasan transformasi pasar desa menjadi Pasar Rintisan TKI. Transformasi adalah perubahan rupa baik bentuk, sifat, fungsi, dan sebagainya. Transformasi adalah sebuah proses perubahan secara berangsur-angsur sehingga sampai pada tahap ultimate, perubahan yang dilakukan dengan cara memberi respon terhadap pengaruh unsur eksternal dan internal yang akan mengarahkan perubahan dari bentuk yang sudah dikenal sebelumnya melalui proses menggandakan secara berulang-ulang atau melipatgandakan. Gagasan untuk menghidupkan kembali pasar desa yang telah mati dan didukung kepentingan mantan TKI untuk mengelola dan mengembangkan hasil kerjanya.

Keinginan membangun desa inilah yang menjadi dasar pemikiran dan alasan kuat membangun dan memanfaatkan lahan pasar mati. Hal pertama yang dilakukan adalah menemui kepala desa

Membangun Ekonomi Rakyat, Inti pemikiran yang termuat dalam tulisan ini pernah diajukan pada Kongres Kebudayaan V, Bukittinggi, tgl 20- 22 Oktober 2003

38 Fatimah, Psikologi Perkembangan, (Bandung: CV Pustaka Setia, 2006), h. 145 
Labuhan Ratu yang saat itu dijabat oleh pak Fahrul untuk meminta ijin pemanfaatan lahan pasar yang telah mati suri untuk dihidupkan kembali. Hal ini dibenarkan oleh pak Fahrul sebagai kepala Desa saat itu. Menurut pak Fahrul menyatakan bahwa pada sekitar tahun tahun 2011 beberapa orang mendatangi kantor desa yang berada di sekitar lapangan desa Labuhan Ratu Kecamatan Way Jepara Kabupaten Lampung Timur untuk menyampaikan aspirasi dan meminta izin serta pertimbangan dari kepala desa, dengan tujuan mendapatkan izin dan persetujuan untuk dapat memanfaatkan lahan pasar gunung terang yang telah lama tidak berfungsi, ${ }^{39}$ dan tanpa penghuni untuk dihidupkan kembali. Melihat dan memperhatikan niatan baik dari para mantan TKI tersebut kepala desa memberikan izin pemafaatan lahan pasar tersebut. ${ }^{40}$ Akhirnya, ada 15 TKI dan Mantan TKI yang mau bergabung dan membangun ruko dan toko di pasar tersebut. Jaringan (network) yang ada dimanfaatkan dengan baik oleh Imam untuk mencapai tujuan untuk menbangun produktifitaas dan kemandirian TKI di Lampung Timur. Dan alhasil pada tahun 2011 dicetuskan pasar rintisan TKI yang diremikan oleh Kepala BNPTKI yang saat itu. ${ }^{41}$

Bahwa Tindakan kolektif yang tinggi yang dilakukan oleh Imam Nahrowi ${ }^{42}$ dan kawan-kawan dan masyarakat desa Labuhan Ratu Lampung Timur dalam meningkatkan kemandirian mantan

39 Pak Fahrul, mantan Kepala Desa Labuhan Ratu, wawancara, 3 Agustus 2018

40 Pak Fahrul, mantan kepala desa Labuhan Ratu, wawancara tanggal 3 Agustus 2018.

41 Imam Nahrowi, mantan TKI Korea, Pelopor Pasar Rintisan TKI, wawancara, 6 Agustus 2018

42 Mantan TKI Korea asal Way Jepara yang kini telah menjadi pengusaha sukses dan menjadi pelopor pasar rintisan TKI. Dalam hidupnya ia berpegang pada rinsip "Jangan menempatkan seluruh modal anda hanya pada satu jenis usaha (Don't put your eggs into one basket)", sekalipun usaha tersebut memiliki prospek yang sangat menjanjikan. Untuk itu saya saat ini mencoba melakukan diversifikasi usaha kecil-kecilan disamping tetap menekuni usaha utama yaitu toko material dan bahan bangunan. Sebagai anak yang lahir dari keluarga petani, saya tetap terobsesi oleh hasil pertanian, oleh karena itu saya menginvestasikan sebagian modal untuk usaha perkebunan karet. Adapun dalam bidang industri, saya mendirikan dua unit pabrik genteng. Masih erat kaitannya dengan bahan bangunan, saya berinvestasi dalam bidang usaha penyewaan peralatan bangunan, seperti mesin molen, scaffolding, dll. Saat ini saya sedang menjajaki kemungkinan membuka usaha trevel dan property sudah berjalan. 
TKI di daerah tersebut dengan membangun pasar rintisan TKI bersama pada masyarakat desa setempat tidak mungkin hadir begitu saja. Kepercayaan kepala desa yang dimanfaatkan secara optimal, dan jaringan antar sesama mantan TKI ternyata mampu menghasilkan sebuah karya yang dapat dinikmati oleh banyak pihak. Partisipasi dan kerja sama yang secara nyata terlihat pada mantan TKI yang nyatanya timbul dalam kondisi modal sosial yang kuat. Ayu Kusumastuti dalam artikelnya menyatakan bahwa Modal sosial sebagai mana di atas kemudian lebih dikenal dengan modal sosial bonding yaitu modal sosial antara individu dalam sebuah kelompok dengan melihat orientasi ke dalam (inward looking). Kerja sama dan partisipasi ini terus dinamis menyesuaikan modal sosial bonding yang hadir di masyarakat. ${ }^{43}$

$\mathrm{Hal}$ di atas terkesan bertentangan dengan Wooolcock yang menyatakan bahwa dalam konteks keeratannya dan keberagaman, modal sosial terklasifikasi menjadi tiga jenis modal sosial, yaitu: (i) Bonding, (ii) Bridging, dan (iii) Linking. "Bonding sosial capital, which denotes ties between like people in similar situations, such as immediate family, close friends and neighbours. "Ikatan perasaan diantara orang-orang yang ada dalam situasi yang sama, semisal ikatan keluarga, kawan karib, dan ketetanggaan). Sdangkan Bridging sosial capital, which encompasses more distant ties of like persons, such as loose friendships and workmates; and (Bridging adalah ikatan modal sosial yang lebih luas dan lebih longgar, seperti pertemanan dan rekan kerja). Linking sosial capital, which reaches out to unlike people in dissimilar situations, such as those who are entirely outside the community, thus enabling members to leverage a far wider range of resources than are available within the community (linking adalah ikatan modal sosial yang angggotanya dari beragam latar belakang, semisal satu komunitas dengan pihak luar, dan ikatan yang demikian akan memungkinkan kita bisa mengakses beragam sumber untuk kepentingan komunitas). ${ }^{44}$ Sehingga dapat disimpulkan keeratan

43 Ayu Kusumastuti, Modal Sosial dan Mekanisme Adaptasi Masyarakat Pedesaan dalam Pengelolaan dan Pembangunan Infrastruktur, jurnal Dipublikasikan oleh: LabSosio, Pusat Kajian Sosiologi FISIP-UI Diterima: Juli 2015; Disetujui: September 2015

44 Michael Woolcock, Sosial Capital and Economic Development: toward a theoretical 
yang dimiliki mantan TKI ini adalah modal sosial linking. Hal ini dikarenakan karakteristik keorganisasi dan persamaan satu nasib dan perjuangan menjadi pengikat mantan TKI untuk berkumpul dan berserikat sesama mantan TKI, yang pada akhirnya menghassilkan gagasan dan kolektifitas kerja yang tinggi untuk mencapau tujuan yakni mandiri dalam berkarya dan mandiri dalam ekonomi.

Aktifitas pedagang mantan TKI di pasar rintisan TKI ini, setiap harinya sibuk di pasar dengan aktifitas perdagangannya. Katami (48) pemilik kios pecah belah. Diketahui adalah seorang purna pekerja migran Indonesia (PMI) dari Lampung Timur. Lebih dari lima tahun ia menghabiskan waktunya untuk berniaga di pasar yang awalnya dirintis alumni TKI. Blok tempat kios Katami berdiri, terlihat penuh terisi. Ada kios sepeda dan onderdilnya, kios furniture, kios pakaian, kios foto copy, dan pulsa. Beberapa blok kios lainnya terlihat tak berpenghuni. Aktivitas jual beli pun terasa senyap tak bergairah pada siang itu. ${ }^{45}$

Selayaknya anggota masyarakat, tentu tidak akan terlepas dari interaksi sosial yang ada dan berkembang di masyarakat. Dari interaksi sosial ini akan muncul hubungan sosial yang dapat berguna dalam pengembangan usaha. Dukungan sosial berupa modal sosial dalam temuan lapangan dapat penulis kategorikan dalam beberapa bentuk. Petama, Kepercayaan (Trust). Trust sebagaimana diartikan oleh Fukuyama merupakan harapan yang tumbuh di dalam diri masyarakat yang ditunjukkan dengan perilaku yang jujur, dan kerjasama berdasarkan norma yang dianut bersama. Lewicki, R.J. and Wiethoff mendefinisikan Trust sebagai keyakinan individu dalam, dan kesediaan untuk bertindak atas dasar, kata-kata, tindakan, dan keputusan orang lain. ${ }^{46}$

Kepercayaan ini menjadi salah satu unsur yag sulit dipisahkan dari masyarakat terutama masyarakat pasar yang sedang menjadi

synthesis and policy framework, Theory and Society, dalam John Field, Sosial Capital, (Canada: Roudledge, 2008), h. 46.

45 Pasar Gunung Terang Labuhan Ratu kabupaten Lampung Timur, observasi, .... 46 Lewicki, R.J. and Wiethoff, Trust, Trust Development and Trust Repair. In: Deutsch, M. \& Coleman, P.T., Eds., The Handbook of Conflict Resolution: Theory and Practice, (San Francisco: Jossey-Bass, 2000), h. 87 
obyek dari penelitian ini. Hal ini tampak dari proses awal adanya pasar rintisan TKI yang hanya mengandalkan saling percaya antara perangkat desa yang dalam hal ini yang empunya otoritas atas tanah dan pasar Gunung Terang, dengan para mantan TKI yang dalam hal ini sebagai pihak yang ingin memanfaatkan lahan pasar sebagai tempat para mantan TKI memanfaatkan hasil kerja selama di luar negeri sebagai buruh migrant.

Munculnya kesepakatan akan pemanfaatan lahan pasar oleh para mantan TKI ini berawal dari keinginan para amantan TKI membangun desa dan memanfaatkan lahan pasar mati yang lama tak berpenghuni. Sebenarnya lahan pasar ini telah digunakan dan oleh desa memang diperuntukkan pasar sejak tahun 1960-an, namun beberpa kali mengalami kemunduran bahkan menjadi tak berpenghuni. Melihat kondisi pasar yang demikian serta didukung oleh kepentingan mantan TKI untuk mengolah hasil kerjanya agar tetap produktif, maka hasil pertemuan antara perangkat desa yakni kepala desa Labuhan Ratu yang saat itu dijabat oleh pak Fahruldengan Imam Nahrowi dan kawan-kawan sebagai perwakilan para buruh migran menghasilkan kesepakatan bahwa aparat desa memberikan izin pemanfaatan lokasi pasar tersebut untuk dihidupkan kembali dengan beralih nama dari pasar desa Gunung Terang menjadi Pasar rintisan TKI, dengan tanpa kompensasi apapun, hanya membayar 500 ribu untuk mendapatkan ijin mendirikan bagungan. Kesepakatan ini terjadi pada tahun 2011 lalu di kediaman kepala desa Labuhan Ratu. Kesepakatan ini terjadi menurut pak Fahrul, pada saat itu pak Fahrul melihat niatan baik dari para mantan TKI dan kepercayaan kepada warga yang ingin membangun desanya, maka harus di dukung. ${ }^{47}$

Hal yang menarik dari paparan di atas adalah adanya kesepakatan yang tanpa konpensasi, kepercayaan yang tinggi yang diberikan aparat desa kepada para mantan TKI yang ingin menghidupkan kembali. Karena hal ini tak mungkin terjadi tanpa

47 Fahrul, mantan kepala desa Labuhan Ratu, wawancara tanggal 3 Agustus 2018. 
adanya kepercayaan yang tinggi. Kepercayaan dan komitmen memegang peranan penting dalam terciptanya suatu hubungan bisnis yang baik. Beberapa studi telah mengungkapkan pentingnya kepercayaan dalam suatu hubungan bisnis. Karakteristik kepercayaan tingkat tinggi dari hubungan pertukaran memungkinkan pelaku untuk fokus pada keuntungan keuntungan jangka panjang hubungan. Kepercayaan dapat meningkatkan daya saing dan mengurangi biaya transaksi. Kepercayaan pada level ini dinamai high trust. Ada beberapa faktor yang turut mempengaruhi tingginya kepercayaan seseorang kepada orang lain. Lewicki, R.J. and Wiethoff, C, dalam tulisannya yang berjudul Trust, Trust Development and Trust Repair, menyatakan bahwa Individu mengembangkan harapannya mengenai tingkat bagaimana seseorang dapat percaya (trust) kepada orang lain, bergantung pada faktor-faktor di bawah ini yakni, pertama, explaining differences in the individual propensity to trust. (menjelaskan perbedaan dalam individual propensity untuk mempercayai). Kedua, understanding dimensions of trustworthy behaviour (dimensi perilaku yang dapat dipercaya). Ketiga, suggesting levels of trust development (menunjukkan tingkat kepercayaan pengembangan). ${ }^{48}$ Berdasarkan teori ini bahwa kepercayaan kepala desa kepada para mantan TKI lebih dikarenakan reputasi Imam Nahrowi sebaagai koordinator mantan TKI, dengan itu membentuk harapan yang kuat yang membawa individu untuk melihat elemen untuk trust dan distrust serta membawa pada pendekatan pada hubungan untuk saling percaya.

Setelah mendapatkan ijin dan kepercayaan (trust) dari kepala desa para mantan TKI mulai menggarap dan mempersiapkan pemetaan pasar tersebut. Selanjutnya para mantan TK dan keluarga TKI menyiapkan bangunan toko dan ruko yang akan mereka gunakan untuk berniaga. Lalu ia menghubungi beberapa rekannya yang masih berada di luar negeri untuk mulai berniaga di pasar tersebut. Bagi yang setuju akan dibangunkan ruko dan terlebih

48 Lewicki, R.J. and Wiethoff, Trust, Trust Development and Trust Repair, In: Deutsch, M. \& Coleman, P.T., Eds., The Handbook of Conflict Resolution: Theory and Practice, (San Francisco: Jossey-Bass, 2000). 
dahulu dan dapat membayar kemudian. ${ }^{49}$

Dari proses diatas tampak bahwa kepercayaan (trust) begitu nyata dan dapat dirasakan. Upaya memberikan cas bon pada para mantan TKI dan TKI yang masih aktif merupakan bentuk kepercayaan dengan level tinggi (bigh-trust). Ada beberapa alasan yang diungkapkan yakni, pertama, bahwa mereka yang meminta untuk dibangunkan ruko dan toko terlebih dahulu adalah kawan yang sudah kenal baik, kedua, kebetulan usaha yang ditekuni Imam Nahrowi adalah toko bangunan ${ }^{50}$, ketiga, tujuannya untuk menghidupkan pasar demi kemandirian para mantan TKI dan TKI yang masih aktif dapat terbangun. Hal ini diungkapkan pada tulisannya yang berjudul Ikhtiar Membangun Kemandirian Ekonomi Tenaga Kerja Indonesia (TKI), dalam tulisannya ia menyatakan bahwa menjadi Tenaga Kerja Indonesia (TKI) yang bekerja di luar negeri pasti bukan merupakan cita-cita siapapun. Dengan kata lain, menjadi TKI merupakan keputusan yang diambil sebagai konsekwensi atas sulitnya mendapatkan pekerjaan didalam negeri. Dengan demikian Seorang TKI dapat dikatakan mandiri secara ekonomi, ketika TKI tersebut telah memanfaatkan uang yang diperolehnya dari menjadi TKI untuk merintis usaha produktif atau menginvestasikannya secara tepat dan terencana dengan sebaikbaiknya. Dengan investasi yang bijak, modal yang ia dapatkan dari bekerja di luar negeri akan dapat berkembang dan menghasilkan keuntungan yang memungkinkannya menatap masa depan yang lebih baik lagi. ${ }^{51}$

Kedua, Norms (norma). Norma adalah tata nilai yang dirumuskan, dilaksanakan dan dijaga bersama untuk mencapai tujuan bersama. Maka, bagi masyarakat, norma memberikan (1) merupakan

49 Imam Nahrowi, mantan TKI Korea, Pelopor Pasar Rintisan TKI, wawancara, 6 Agustus 2018

50 Menurut Imam toko bangunan itu lebih menjanjikan alasannya barang tidak mudah busuk, semua orang yang ingin membangun rumah ataupun toko pasti membutuhkan material bangunan. Kini toko bangunanya ada 5 cabang yang menyebar di daerah Kabupaten lampung Timur.

51 Imam Nahrowi, Ikbtiar Membangun Kemandirian Ekonomi TKI, artikel tidak diterbitkan. 
pedoman berperilaku bagi antar individu dan apa yang mesti mereka lakukan; (2) merupakan alat penjaga keutuhan eksistensi masyarakat tertentu. Suatu masyarakat akan disebut eksistensinya jika mereka memiliki norma yang berlaku dan disepakati bersama, apabila tidak ada maka tidak ada masyarakat melainkan hanya sekumpulan benda. (3) Merupakan alat bagi sesama anggota dalam melakukan kontrol sosial.

Ketiga, Network (jaringan). Network atau jejaring adalah model hubungan diantara para anggota masyarakat atau organisasi sosial. Manusia memang kalau hanya untuk sekedar tidak mati, bisa melakukan berbagai hal secara sendiri. Namun, ia akan mengalami kepayahan yang amat sangat. Bayangkan saja, satu orang jika ingin makan, maka ia harus mencari bahan baku sendiri di hutan lalu menemukan tanaman yang bisa dimakan, untuk memiliki pakaian ia harus membuat pakaian sendiri, dari mulai menanam kapas, memintal, menenun, dan menjahit. Untuk memiliki rumah, ia harus mencari kayu sendiri, menebang pohon sendiri, memikul kayu sendiri, membelah, dan menyerut kayu serta membentuknya menjadi rumah. Betapa payahnya manusia jika demikian. Maka, manusia memerlukan bantuan orang lain.

Dalam konteks masyarakat, ada banyak tujuan dari berdirinya masyarakat. Maka, jejaring atau network adalah demikian penting bagi mereka. Dengan network, manusia bisa memperoleh keinginan dan memenuhi kebutuhan hidupnya dengan sangat mudah, nyaman, dan efektif serta optimal. Misalnya: Untuk mengetahui apakah rumah sakit di kota sudah buka dan memberikan layanan, kita tidak harus datang langsung dan melihat atau bertanya di rumah sakit, namun cukup dengan SMS ke orang yang kita percaya (we trust to bim/ her) dan bertanya. Demikan juga jika kita ingin mengetahui apakah perguruan tinggi itu baik ataukah jelek, atau tentang kebutuhan lainnya. Jika seseorang memiliki kesamaan nilai, maka mereka lebih cenderung bekerjasama untuk mencapai tujuan bersama. ${ }^{52}$

52 John Field, Modal Sosial, judul Asli Social Capital, Penterjeman Nurhadi, (Bantul: Kreasi wacana, 2018), h.4 
Salah satu bentuk modal sosial yang ada dan diuri-uri dipasar ini adalah jaringan (networks), yang menurut Barnes jaringan sosial sebagai suatu angkaian hubungan-hubungan yang dibuat oleh seorang individu di sekitarnya daanberpusat pada dirinya, berdasarkan kehendak pribadinya.individu yang melakukan komunikasi dan interaksi yang secara intensif akan membangun jaringan yang kokoh. Jaringan sosial yang dibangun tiap individu di dalamnya dapat menjadi fasilitas yang memberi manfaat dan dapat menggerakkan kegiatan yang berlangsung sehari-hari.

Dalam konteks mantan TKI yang ingin membangun pasar desa menjadi pasar rintisan TKI ini tentumelibatkan banyak pihak yang akan turut memperkokoh jaringan sosial yang ada. Keberadaan jaringan sosial ini member manfaat bagi setiap pihak yang terlibat. Dalam kajian ini jaringan sosial dimaknai sebagai kerjasama dengan berbagai pihak yang dilakukan untuk mempertahankan usaha. Para pedagang pasar yang notabene adalah mantan TKI dan keluarga TKI initentu dalam menjalankan usahanya tidak sendirian. Mereka membentuk jaringan usaha sesama mantan TKI. Perkumpulan ini bukan hanya menaungi satu jenis usaha tetapi seluruh jenis usaha yang dirintis oleh mantan TI dan keluarga TKI. Perkumpulan ini secara rutin mengadakan pertemuan 1 bulan sekali dalam rangka menjada ghirah usaha masing-masing supaya tidak cepat putus asa dengan perkembangan usahanya. Karena tidak sedikit dari anggota perkumpulan ini yang merasa tidak sabar mengelola usahanya di tanah air dan memilih kembali keluar negeri, karena dianggap lebih instan. Hal ini tentu memprihatinkan.

Keempat, Reciprocity (Hubungan Timbal-Balik). Reciprocity merupakan tindakan bersama yang ditunjukkan dengan saling memberi respon. Dalam bahasa lain hubungan timbal-balik. Jadi, reciprocity ada dua jenis, yaitu: Direct reciprocity (timbal-balik langsung) dan Continum reciprocity (timbal-balik beralur). Karena adanya kepercayaan yang tinggi antar anggota, aturan bersama tak tertulis yang dilaksanakan, dan jaringan sesama mantan TKI yang kuat maka 
hubungan timbale balik adalah sebuah konsekuensi logis. Hubungan timbal balik yang terjadi bukan hanya sekedar nama atau slogan tetapi sebah keniscayaan dari kepercayaan yang terjalin. Hubungan timbal balik inilah yang kemudian menjadikan anggota pasar Labuhan Ratu sebagai sesama mantan TKI yang senasib sepenanggungan untuk saling membantu, saling menguatkan dan saling memotivasi untuk mencapai kemandirian.

\section{Simpulan}

Kemandirian ekonomi dapat diwujudkan dengan memanfaat modal sosial yang dimiliki, yakni pertama, kepercayaan (trust). Kepercayaan yang tinggi (bight trust) akan menghasilkan kemauan dan keberanian untuk bekerjasama dengan stakeholder terkait. Kedua, Norm (tatanan/pranata sosial yang berlaku). Norma yang disepakati bersama memicu orang selalu bertindak dasar kesepakatan dan tujuan bersama dari komunitas mantan TKI yang sedang membangun kemandirian ekonomi. Ketiga, Network (jaringan antar anggota), jejaring yang kuat menjadikan para mantan TKI cepat mendapatkan informasi baik berkaitan dengan pemasok, peluang pasar, dan peluang usaha baru, serta peluang mendapatkan pendidikan pelatihan bekerjasama dengan pihak luar. Keempat, Reciprocity (hubungan timbal-balik), hubungan timbal balik inilah yang kemudian menjadikan anggota pasar Labuhan Ratu sebagai sesama mantan TKI yang senasib sepenanggungan untuk saling membantu, saling menguatkan dan saling memotivasi untuk mencapai kemandirian.

Untuk melihat seberapa besar modal sosial memberikan pengaruh terhadap peningkatan kemandirian mantan TKI. Secara garis besar modal sosial memberikan pengaruh positif bagi peningkatan kemandirian TKI di Labuhan Ratu Lampung Timur. Hal ini dibuktikan dengan majunya pasar Gunung Terang Labuhan Ratu dan usaha yang masih berkelanjutan yang berimplikasi pada meningkatnya perekonomian dan kemandirian mantan TKI sebagai pedagang di dalamnya. 


\section{DAFTAR PUSTAKA}

Ayu Kusumastuti, Modal Sosial dan Mekanisme Adaptasi Masyarakat Pedesaan dalam Pengelolaan dan Pembangunan Infrastruktur, Jurnal Dipublikasikan oleh: LabSosio, Pusat Kajian Sosiologi FISIP-UI Diterima: Juli 2015; Disetujui: September 2015

Barly Sputra Utama. Kasi Penempatan Tenaga kerja Lampung Timur. Diakses tanggal 11 Oktober 2017. https:/ / kupastuntas.com

Castiglione, et.al.. Social Capital's Fortune : An Introducti,. In Dario Castiglione, et.al (ed), The Handbook of Social Capital, (New York : Oxford University Press Castiglione, et.al, 2008.

Dodi Faedlulloh, Modal Sosial Dalam Gerakan Koperasi, Jurnal: IJPAThe Indonesian Journal Of Public Administration, Volume 2, Nomor 1, Nopember 2015

Fatimah, Psikologi Perkembangan, Bandung: CV Pustaka Setia, 2006.

Glenn A Bowen, Sosial Capital, Social Fund And Poor Community, An Explory Analysis, Journal Compilation, Social Policy And Administrations, Oxford: BlackwellPublishing Ltd, 2009.

Imam Nahrowi, Mengembangkan Ekonomi TKI, Peluang dan tantangan (sebuab pemikiran), artikel tidak diterbitkan.

J.P. Chaplin, Kamus Lengkap Psikologi, Jakarta: RajaGrafindo Persada, 2011.

Jannes Eudes Wawa, Ironi Pablawan Devisa, Jakarta: PT Kompas Media Nusantara, 2005.

John Field, Modal Sosial, Bantul: Kreasi Wacana, 2010. , Modal Sosial, judul Asli Social Capital, Penterjeman Nurhadi, Bantul: Kreasi wacana, 2018.

Lewicki, R.J. and Wiethoff, Trust, Trust Development and Trust Repair. 
In: Deutsch, M. \& Coleman, P.T., Eds., The Handbook of Conflict Resolution: Theory and Practice, San Francisco: JosseyBass, 2000.

Lindon J Robinson, A. Allan Schmid, Marcelo E. Siles. Is Social Capital Really Capital, Review Of School Ecomony, 2000. http:/ / papers.ssrn.com

M Moelyono, Menggerakkan Ekonomi Kreatif Antara Tuntutan dan Kebutuhan, Jakarta: PT. Raja Grafindo Persada, 2010.

Michael Woolcock, Sosial Capital and Economic Development: toward a theoretical synthesis and policy framework, Theory and Society, dalam John Field, Sosial Capital, Canada: Roudledge, 2008.

Monks, dkk, Psikologi Perkembangan: Pengantar Dalam Berbagai Bagian, Yogyakarta: Gadjah Mada University Press, 1994.

Pheni Chalid, Peranan Modal Sosial Dalam Kegiatan Ekonomi, Signifikan Vol. 1 No. 1 April 2012. , Sosiologi Ekonomi, Jakarta: CSES Press, 2009.

R.D Putnam, Bowling Alone: The Colapse and Revival of American Community, New York: Touchstone, 2000.

Robert Putnam, Democracies in Flux: The Evolution of Social Capital in Contemporary Society, New York: Oxford University Press, 2002.

Sri-Edi Swasono, Kemandirian Ekonomi: Menghapus Sistem Ekonomi Subordinasi Membangun Ekonomi Rakyat, Inti pemikiran yang termuat dalam tulisan ini pernah diajukan pada Kongres Kebudayaan V, Bukittinggi, tgl 20-22 Oktober 2003.

St Agung Dwi Pramono, Pengaruh Modal Sosial Terhadap Kemiskinan Rumah Tangga, Jurnal: Jejak, Vol 7

Takashi Omori, Economic Effects Of Sosial Capital, Economic and Sosial 
Research Institut, Cabinet Office, Government Of Japan, March 2003.

The World Bank, The Initiative On Defining, Monitoring And Measuring Social Capital: Text Of Proposal Approved For Funding, Social Capital Initiative working paper No. 2 the world bank development family, environmentally and socially sustainable development network, June 1998 (dalam http://.worldbank. org yang dikutip dalam syahyuti, Social Capital, Pusat Kebijakan Sosial ekonomi dan Pertanian IPB.

Yulvianus Harjono, Memelopori Pasar Rintisan Mantan TKI. Diakses tanggal 4 Oktober 2017. http://internasional.kompas.com.

Sevita Dwi Yani, Banyak Remaja Menjadi Burub Migran Karena Dorongan Orang Tua. Diakses 5 Agustus 2018. https://buruhmigran. or.id.

NN. Alasan Penyebab Seseorang Menjadi TKI (Tenaga Kerja Indonesia) ke Luar Negeri. Diakses 5 Agustus 2018. http:/ /www.organisasi. org.

. Lampung Timur Penyumbang Pekerja Migran Terbanyak. Diakses tanggal 3 Mei 2018. http://www.lampost.com.

. Diakses tanggal tanggal 27 April 2017. https://bisnis.tempo. com.

. https://kbbi.kemdikbud.go.id/entri/kemandirian

. UMR DKI Jakarta tabun 2017. Diakses tanggal 28 Oktober 2016. http://bisnis.liputan6.com. 